Media Industries 6.2 (2019)

\title{
Political Goals versus Commercial Goals: Emile de Antonio's Rush to Judgment on the Market
}

\author{
Nora Stone $e^{1}$ \\ UNIVERSITY OF ARKANSAS AT LITTLE ROCK \\ norastone [AT] gmail.com
}

\begin{abstract}
Emile de Antonio had reason to hope that his second documentary, Rush to Judgment(1967), would be as popular as his first, Point of Order! (1963). Made with bestselling author and political commentator Mark Lane, Rush to Judgment was one of the very first films to question the Warren Commission's conclusion about the Kennedy assassination. However, despite its topicality, Rush to Judgment did not entice exhibitors or audiences. While de Antonio and others attributed the film's commercial failure to politically motivated censorship and intimidation, this explanation does not account for other factors in the documentary's release. Using trade journals and Emile de Antonio's archive, this article finds that Rush to Judgment's release was hobbled by an inexperienced and dysfunctional distribution company and by de Antonio and Lane's divergent goals. Most of all, though, the instability of the independent film market in the mid-1960s sunk the release of Rush to Judgment.
\end{abstract}

Keywords: Film Distribution, Documentary, Committed Documentary, Political

Emile de Antonio's first film, Point of Order!, was a surprise success at the box office in 1964. Made with Dan Talbot, owner of the recently opened arthouse New Yorker Theater and later founder of distribution company New Yorker Films, Point of Order! tells the story of the infamous Army-McCarthy hearings of 1954. Distributor Walter Reade-Sterling booked Point of Order! in over one hundred cinemas, as well as numerous college campuses. This was the beginning of de Antonio's illustrious career as a leftist documentarian during the Cold War years. His films covered the most incendiary topics of the day, including the McCarthy hearings, the assassination of President John F. Kennedy (JFK), the Vietnam War, the character of President Richard M. Nixon, the Weather Underground, and nuclear proliferation. His film about American involvement in Vietnam, In the Year of the Pig, was recognized with a nomination for an Academy Award for Best Documentary in 1969. 
In subject matter, de Antonio's films were extremely topical. He targeted issues when they were acute, rather than waiting for tempers and memories to mellow. Although de Antonio's films explored the major touchstones of postwar America, he resisted the style of filmmaking that defined American documentaries of the 1960s and 1970s: Direct Cinema. Rather than using the new technologies of light $16 \mathrm{~mm}$ cameras and wireless sync sound recorders to be a "fly on the wall," de Antonio adopted the interactive mode of documentary. ${ }^{2}$ The interactive mode does not offer a sense of unmediated access to the world; rather, it foregrounds the filmmaker's participation in or organization of the world. De Antonio's voice is rarely heard in his early films, but he is present as the organizing intelligence behind the films' arguments. Generally eschewing voiceover narration, de Antonio made historical documentaries through compilation, building a story and an argument by cobbling together interviews, television news footage, and other audiovisual materials. Often juxtaposing contradictory materials, this aesthetic collage gave the films a combative tone. Douglas Kellner and Dan Streible emphasize the radical nature of de Antonio's politics and aesthetics, writing, "De Antonio's legacy is that of a political modernist, providing models of creative film form that exploit the archives of history in a way that speaks truth to the ideology of dominant powers."3

De Antonio was hopeful that his second film, Rush to Judgment (1967), would be another hit, cementing his reputation and allowing him to find funds for his next film projects. He partnered with Mark Lane, the attorney hired to posthumously represent Lee Harvey Oswald before the Warren Commission. In the film, Lane interviews witnesses to the assassination of President Kennedy who were not called to testify before the Warren Commission. Helicopter shots of Dealey Plaza illustrate the witnesses' accounts at key points. Based on Lane's book of the same title, the Rush to Judgment film makes a convincing argument for the biased and incomplete nature of the 1964 Warren Report, although it stops short of proposing the kind of conspiracy theory that would subsequently proliferate in popular culture. Both book and film were among the very first to question the conclusions reached by the Warren Commission, capitalizing on current events and the climate of public opinion.

However, Rush to Judgment's topicality did not entice exhibitors or audiences, nor were American television networks interested in broadcasting it. What could cause a film with such sensational subject matter and cultural currency to fail commercially? To understand this commercial disappointment, one must investigate the context of its release. Rush to Judgment was distributed by an inexperienced and dysfunctional company, and the film's rollout was compromised by de Antonio and Lane's divergent goals. Most of all, though, the instability of the independent film market in the mid-1960s hobbled the release of Rush to Judgment. There were few distribution companies interested in acquiring politically engaged or aesthetically adventurous independently made features and few theaters that programmed those films. American television networks broadcast nonfiction programs during the 1960s. Light entertainment documentaries drew strong ratings. But networks were loathe to acquire public affairs documentaries that would usurp editorial control from their in-house news departments. ${ }^{4}$

The commercial failure of Rush to Judgment reflects the fickle state of documentary cinema in the mid-1960s. Although the era produced many well-remembered and critically lauded documentaries, particularly classics of the Direct Cinema movement like Crisis: Behind a Presidential Commitment (1963, dir. Robert Drew) and Salesman (1969, dir. Maysles), the 
commercial possibilities for documentary films were severely limited. Only documentaries that promised lurid sights, like Mondo Cane (1963, dir. Gualtiero Jacopetti), or engaged with popular and youth culture, like Monterey Pop (1968, dirs. Richard Leacock and D.A. Pennebaker), gained traction at the box office. Network television was equally unwelcoming to documentary films, despite the networks' short-lived alliances with Robert Drew Associates.

Using trade journals and the papers of Emile de Antonio, I explore the specialty film distribution landscape of the 1960s to give a fuller picture of the market conditions that de Antonio and Lane faced when releasing Rush to Judgment. I also delve into Impact Films, the distribution company that acquired Rush to Judgment, and show how the divergent goals of the film's creators affected its release. The filmmakers' contrary goals invoke one of the thorniest questions about political documentaries and their relationship to the marketplace. Should politically committed films be circulated as commercial products, or should they primarily be used in conjunction with other advocacy activity? The persistent trope of the radical artist "selling out" makes these distribution methods seem mutually exclusive. But they are often entangled, especially when collaborators have conflicting goals.

\section{Tentative Market for Documentaries}

The success of Point of Order! was exceptional. As a black-and-white compilation documentary about events a decade earlier, it would certainly not be the most salable independent film of 1963-1964. Point of Order! played at the first New York Film Festival in 1963, which raised the film's profile but did not guarantee that it would have a theatrical life. Indeed, when no distribution company tendered an offer to acquire the film, de Antonio and Talbot selfdistributed it, opening Point of Order! at Talbot's New Yorker Theater in early 1964. Once its receipts proved that the film had commercial prospects, foreign-film distributor Walter Reade-Sterling picked it up for national distribution. It had a profitable run in theaters and was booked by many colleges and film societies. Nevertheless, its unexpected success in playing over one hundred specialty theaters should be tempered by comparison to documentary breakout Mondo Cane, which played over three thousand dates and grossed more than US\$1 million in 1963, its first year in release by Times Film Corp. ${ }^{5}$ The disparity in performance of these two "successful" documentaries, both released by independent distribution companies, illustrates the uncertain prospects in the market for documentaries at the time.

Yet, by Rush to Judgment's release in 1967, the market for low-budget, "quality" independent films, both fiction and documentary, seemed to have grown. I use the word "quality" to emphasize the filmmakers' aesthetic and political ambitions. The development of lowbudget, "quality" independent films added another mode of production and distribution to the definition of independent film in the United States. In the 1960s, the term "independent" could be taken to mean top-rank independent filmmaking in Hollywood or lowbudget exploitation filmmaking. ${ }^{6}$ Although there had always been commercial independent production, Janet Staiger argues that by 1956, there was a wholesale shift in Hollywood's mode of production, wherein "the package-unit system of filmmaking replaced the older studio system." In the package-unit system, the major studios financed independent film production that had been packaged with star, script, and director by a producer. ${ }^{8}$ Then the 
studios distributed the films. This move toward more and more independent productions meant that, by the late 1960s, "the terms 'top-rank independent' and 'mainstream Hollywood' filmmaking [had become] virtually interchangeable," according to Yannis Tzioumakis. ${ }^{9}$ At the same time, independent producers of exploitation films made lowbudget films in generic cycles with highly marketable titles. Often targeting the youth audience, they were distributed independently. ${ }^{10}$ These types of independent filmmakingtop-rank independent and low-budget exploitation-are distinct from the industrially independent and aesthetically adventurous films being made by the New American Cinema Group and Direct Cinema filmmakers in the 1960s. The release of Rush to Judgment should be understood as separate from the commercial independent films that increasingly dominated Hollywood and generic low-end exploitation films.

Filmmakers in both groups-New American Cinema and Direct Cinema-such as John Cassavetes, Shirley Clarke, Lionel Rogosin, Andy Warhol, Ricky Leacock, and D.A. Pennebaker, had aesthetic and political aims in their filmmaking. Impressed with the foreign art cinema that arrived on American screens starting in 1946, they aimed to make films as inventive, subversive, and personal as those being imported from Europe and Japan. ${ }^{11}$ Also significant is that they devised ways to circulate their films independently. First, they sold distribution rights to small distribution companies such as Cinema V, New Yorker Films, and British Lion International Films - the same companies that distributed foreign art films. Second, they formed their own distribution operations. The New American Cinema Group formed the Film-Makers' Cooperative and the Film-Makers' Distribution Center (FDC), while Direct Cinema filmmakers formed the distribution companies Leacock-Pennebaker and Zipporah Films. When making Rush to Judgment, de Antonio planned to shop it around to the small distribution companies.

I bring together the New American Cinema Group and the Direct Cinema filmmakers for several reasons. These filmmakers were trying to solve the same problem: how to make and circulate films apart from the dominant modes of production and distribution. Warhol hit upon one solution when he began marketing his films as sexploitation and exhibiting them in theaters that showed sex films. However, this was not an option available to most of the other filmmakers. Many of these filmmakers also worked together. De Antonio starred in a 1965 film by Warhol, Drink aka Drunk, and Rogosin helped finance the production of Rush to Judgment. They were also connected in cinephilic discourse of the period, with Direct Cinema filmmakers earning praise from the editors of Film Culture, the magazine of the New American Cinema. Films by both groups played at the nascent New York Film Festival during these years. Finally, this is a conscious intervention in the history of 1960s film industry and culture. Most industrial histories have ignored documentary films in this period or commented upon only the most commercially successful (Woodstock) or the most well remembered (Salesman). This intervention clarifies de Antonio's career trajectory, adding context to the commercial success of de Antonio's first film and the failure of his second film. The 1960s saw a swell of hope for the advancement of low-budget, "quality" independent films in cinemas, especially documentary films. And as a signatory on the First Statement of the New American Cinema, de Antonio believed in these possibilities.

De Antonio was not wrong to believe that the commercial prospects for low-budget, "quality" independent cinema were growing. In 1967, the year of Rush to Judgment's release, Variety noted a new development: For the first time ever, so many high-profile documentaries had been 
released that there was real competition for the Academy Award for Best Documentary. ${ }^{12}$ For example, the independently made surfing travelogue The Endless Summer (dir. Bruce Brown) and Bob Dylan tour documentary Dont Look Back (dir. D.A. Pennebaker) attracted crowds to theaters. Beginning its theatrical run in self-distribution in 1966, Cinema V acquired The Endless Summer and propelled it to a US\$2.1 million gross by the end of 1967. It was one of the toptwenty-grossing films of $1967 .^{13}$ Dont Look Back broke box-office records across the country, outselling expensive Hollywood productions such as Thoroughly Modern Millie (1967, dir. George Roy Hill) even as it was distributed by its own producers' company, Leacock-Pennebaker. ${ }^{14}$

The growing number and financial success of theatrically released documentary films did not necessarily reflect an opening in the specialty cinema market. Distributing independently produced films remained almost as difficult as ever. The overwhelming majority of exhibitors were still wedded to Hollywood studios, in fact if not in name, even after the Paramount decision of 1948 forced the studios to sell off their theater holdings. Without the corporate infrastructure smoothing the logistics of the distribution process, distributors fought to book their films in high-profile theaters in centers like New York City. Even if a film's New York run was successful, it was still difficult to place the film in other cities and transition into wider release. This was true not only for documentarians but also for other independent filmmakers. In 1966, independent and avant-garde filmmakers had founded the FDC in an attempt to book their films in commercial cinemas, but, as James Kreul has shown, the theatrical market continued to elude them. ${ }^{15}$ Failing to break into theaters, the FDC mainly distributed its films on the nontheatrical market.

The nontheatrical market was a more promising avenue for documentary films, as well. While a less prestigious and lucrative route than the theatrical market, it entailed much less risk and lower upfront costs. The nontheatrical market was also growing, thanks to an explosion in university campus film culture. During the 1960s, the number of films exhibited on campuses grew significantly, and foreign-language films and documentaries were exhibited in a volume disproportionate to their commercial presence. According to Andrea Comiskey, documentaries constituted between 6.5 and 16 percent of the films played on college campuses, fourth behind foreign-language films, classic Hollywood repertory, and recent Hollywood releases. ${ }^{16}$

Despite interest in documentaries by film buffs and an increasingly politicized youth, commercial prospects for theatrical release remained low. For instance, in 1967, the fifth New York Film Festival highlighted documentaries in a sidebar program called "The Social Cinema in America," bringing together socially conscious observational works such as Titicut Follies (dir. Frederick Wiseman), Black Natchez (dirs. Ed Pincus and David Neuman), Warrendale (dir. Allan King), and Home for Life (dirs. Gordon Quinn and Gerald Temaner). The films attracted so much interest at the festival that hundreds of ticket buyers had to be turned away. ${ }^{17}$ However, even with demonstrated interest by festival-goers, few of the works were subsequently released theatrically. And among those intrepid distributors that did release documentaries theatrically, as Grove Press did with Titicut Follies and Warrendale, theatrical release was mainly a way to publicize the films prior to their main, nontheatrical distribution. ${ }^{18}$

While de Antonio had a surprise theatrical success with 1964's Point of Order!, the film's high volume of rentals by campus film societies, classes, and other university organizations was a more typical fate for documentaries than conventional theatrical exhibition at the time. 


\section{Rush to Judgment's Distribution History}

In many ways, Rush to Judgment seemed destined to succeed: It was released soon after the book version hit bestseller lists, co-creator and author Mark Lane was a popular guest on radio and television talk shows, and more documentaries were being released theatrically than ever before. Even Motion Picture Herald predicted that Rush to Judgment was a film "which exhibitors should have little difficulty in promoting... inconceivable that patrons across the land and throughout the world would not want to see this 122-minute 'brief for the defense [of Lee Harvey Oswald]'."'19

And yet, almost no distributors were interested in touching it. After rejections from numerous distributors, de Antonio and Lane turned to their last resort: a new company called Impact Films, which was run by one of their investors. Impact Films premiered the film in theaters in New Orleans in March 1967 to capitalize on District Attorney Jim Garrison's inquiry into the JFK assassination, but it earned little money and few accolades. In May 1967, Impact released Rush to Judgment in New York City at the Carnegie Hall Cinema, but it failed to gain traction and open more widely. Rush to Judgment did not make it to the west coast until the following year, when it played at Cinematheque16 in Los Angeles, a nontheatrical venue that showed independent and experimental films. American television networks did not license the film for broadcast, though Rush to Judgment did play on television in the United Kingdom.

De Antonio himself attributed this commercial failure to subtle forms of government intimidation. Scholars have generally followed suit. When numerous British theatrical distributors declined to acquire Rush to Judgment in 1967, de Antonio wrote to one of the film's financial backers that he believed "the CIA is whispering down the secret corridors." ${ }^{20}$ However, there is no evidence to ground claims of intimidation or censorship during the distribution of the film. ${ }^{21}$ Rather, the historical record points to more proximate causes for the disappointing theatrical release of Rush to Judgment: an inexperienced distributor and the creators' divergent goals for the film, combined with a small, tentative theatrical market for documentary films. It is crucial to clarify these structural causes so as not to create a reductionist interpretation of events, wherein political films fail to gain wide release and large audiences only because of opposition to their political stance. In fact, political films operate within a much wider context, with actors who may not be politically motivated and with stakes unrelated to politics. Political films, particularly documentaries, are often produced independently, but to reach audiences they generally must enter the commercial arena, often pursuing a mix of theatrical and nontheatrical distribution and exhibition. Making the films seen is a key element of this process.

It is certainly possible that other distribution companies declined to acquire Rush to Judgment for political reasons. In a letter, de Antonio wrote that Columbia, United Artists, Walter Reade, and Seven Arts all screened cuts of the film. ${ }^{22}$ While executives at these distributors may have shrunk from the film's oppositional message, it is just as likely that they saw little commercial possibilities for the film. In 1965, only a year before Rush to Judgment was completed and offered to distributors, Columbia had released a biographical documentary on Winston Churchill, The Finest Hours (dir. Peter Baylis). In late 1964, United 
Artists had released a documentary about the assassination of President Kennedy and its aftermath, Four Days in November (dir. Mel Stuart). Both commercial disappointments, Four Days in November, for example, played only two hundred engagements in its first seven months in release. While this is double the number of engagements that Point of Order! had during its run, it is nowhere near to the seven thousand to eight thousand engagements an average United Artists film would play. As one distribution executive told Variety in 1965, "It just isn't worth the cost of launching [documentaries] . . And you can't blame exhibitors for not booking them when they have a chance to play a Goldfinger, What's New Pussycat? or Cat Ballou, instead." ${ }^{23}$ Given the tepid response to the two recent historical documentaries, most distribution companies were not willing to pay an advance to acquire a documentary film or finance the print and advertising required to release it. Although Rush to Judgment seemed likely to succeed because of the wide appeal of its subject matter and its association with a bestselling book, the weak institutional framework for releasing documentaries in theaters worked against its appeal.

\section{A Troubled Distribution Company}

Once Rush to Judgment was in the hands of the distributor Impact Films, it was severely handicapped by the company's inexperience and dysfunction. Point of Order! had been distributed by Walter Reade-Sterling, a seasoned distributor of foreign films in America founded in 1954. Failing to secure a more established company, the filmmakers turned to their last resort: Impact Films, run by filmmaker and cinema owner Lionel Rogosin and Max Osen. When Rogosin invested US\$5,000 in the production of Rush to Judgment in March 1966, he stipulated that Impact would distribute the film if the filmmakers could not find another distributor. ${ }^{24}$ Impact Films was a much different company than de Antonio's previous distributor and Rush to Judgment was its first release. It did not go smoothly. De Antonio interrogated Max Osen about the advertising budget, and attacked Rogosin head-on in a letter, in which he enclosed an ad a friend mailed him from San Francisco (Figure 1): ${ }^{.5}$

This ad is about as silly as any I've ever seen and I'm sure your pictures don't go out with ads like enclosed. First of all, what is Rush to Judgment? Its subject? Who made it? Does it have any reference to best selling book of the same name $?^{26}$

Indeed, de Antonio's frustration seems warranted. The small advertisement makes no reference to the potentially sensational topic of the film, nor does it try to mobilize any interest based on the popularity of Lane's book.

Not only that, the ad marketed Rush to Judgment in a traditional manner, using only text from critics' reviews. Impact Films lacked the marketing savvy of another independent distributor, Cinema V. Cinema V successfully promoted its arthouse films by crafting a striking, consistent visual brand identity for releases such as Endless Summer (1966) and Elvira Madigan (1967). ${ }^{27}$

In August 1967, two months after the New York opening of Rush to Judgment at the Carnegie Hall Cinema, Impact Films defaulted on its contract with de Antonio and Lane, leading de Antonio to renegotiate the contract and reduce the initial advance owed from US\$50,000 to US\$25,000. By October of the same year, Rogosin and Osen had dissolved their partnership, 


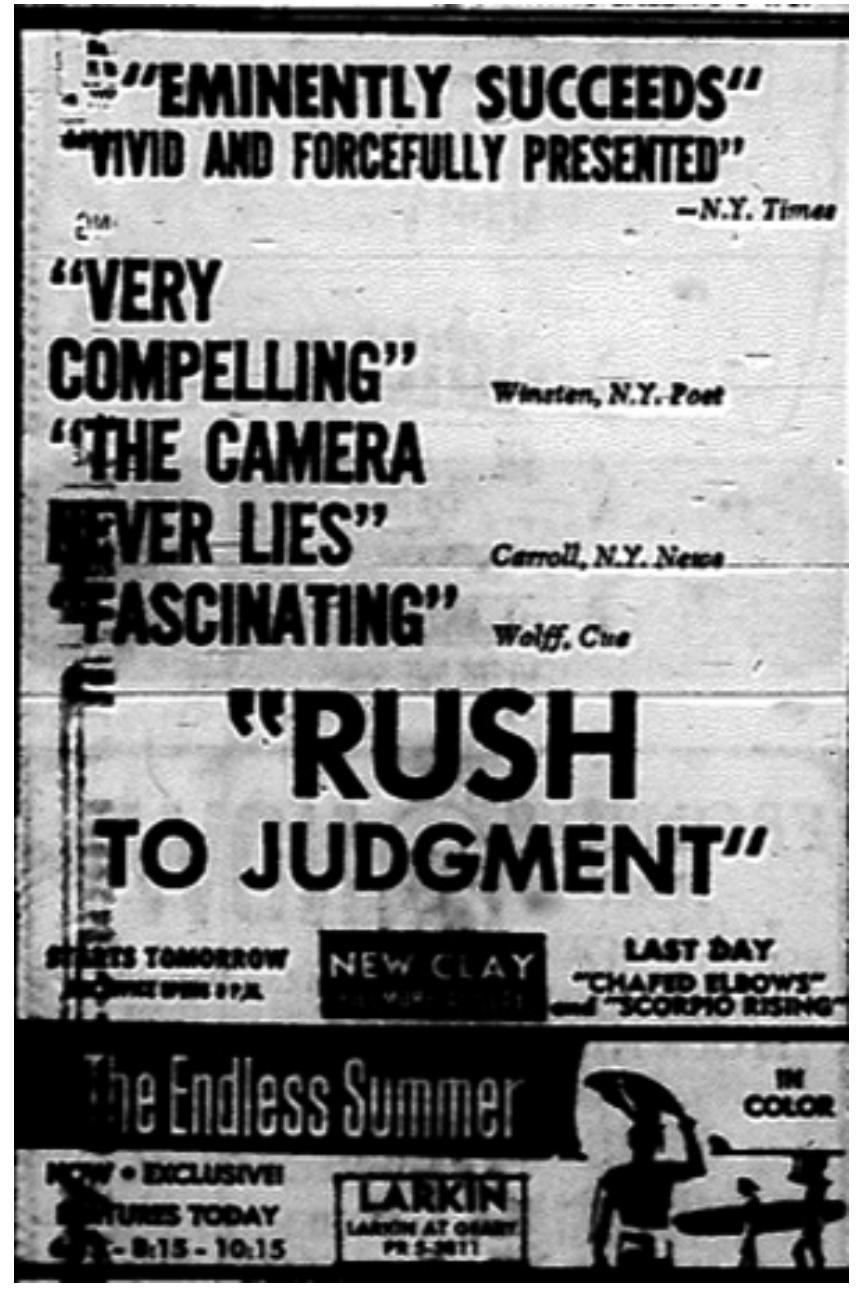

Figure 1. Ad for Rush to Judgment in San Francisco Chronicle, August 10, 1967.

leaving Rogosin to run Impact on his own. Variety reported, "Although the dispute was originally acrimonious and lawsuits were threatened, an 'amicable' settlement was eventually reached." ${ }^{28}$ While the nature of this dispute is unknown, its very existence points to a company in turmoil at the very moment of Rush to Judgment's release. Furthermore, neither of Impact's two principals were experienced theatrical distributors, which likely made the sale of a potentially controversial film to exhibitors more difficult than if it had been handled by experts.

\section{Clashing Goals Lead to Confusion and Failure}

While the distributor's internal troubles and the larger context of American independent cinema at the time hampered Rush to Judgment's commercial possibilities, the film's distribution and exhibition in the United States was likely even more severely compromised by the filmmakers' disparate goals. While de Antonio sought a traditional route to cinematic success-having the film play theatrically, as Point of Order! did, and be broadcast on American television-theatrical distribution was not Lane's top objective (Figure 2). Rather, spreading 


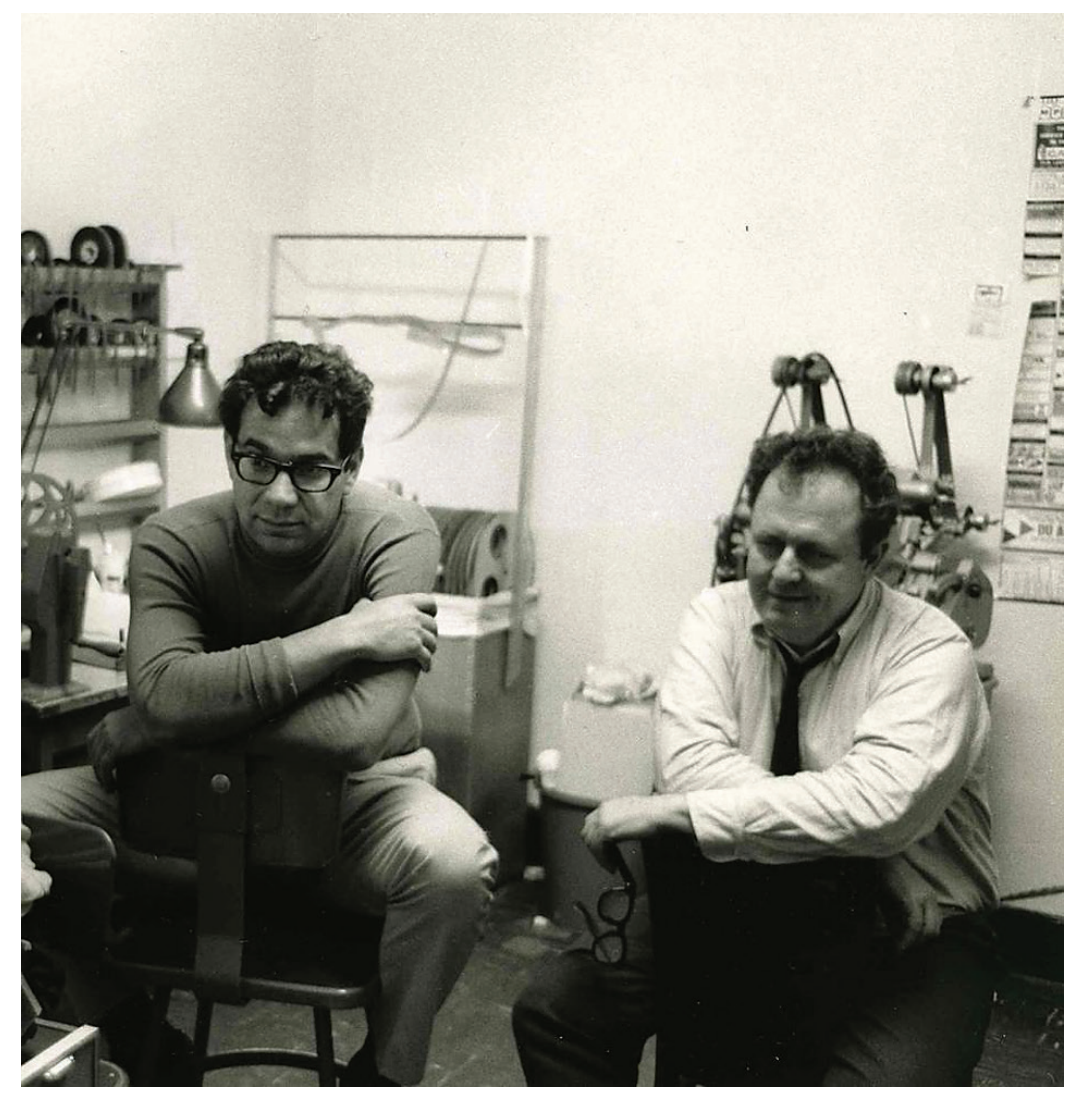

Figure 2. Mark Lane and Emile de Antonio.

Photo from Wisconsin Center for Film and Theater Research.

doubt in the Warren Commission Report and burnishing his own image as a public intellectual were Lane's admitted goals. This led Lane to make deals that were detrimental to Impact's efforts to secure Rush to Judgment's exhibition by saturating the media landscape with the film's content and allowing large excerpts of the film to play on television for free.

De Antonio and Lane's different goals reflect an ongoing question about what documentaries are and where they fit in the media landscape-are political documentaries commercial products whose success should be measured in box-office grosses, or are they one tool of many that activists can use to affect social and political change? Thomas Waugh defines a committed documentary as one that (1) declares "solidarity with the goal of radical sociopolitical transformation" and (2) encourages action in pursuit of that transformation.$^{29}$ Rush to Judgment argues that viewers should adopt a different point of view on a historical event than that offered by an official government committee. But the film's sowing of distrust has no direct connection to any larger political movement or radical ideology. Using Waugh's definition, Rush to Judgment is not a fully committed documentary. Documentaries can be committed in ways beyond the textual, but, as Waugh points out, it is a tough, complicated undertaking. He writes,

To realize a vision of commitment at every stage of a film's trajectory has usually required a miracle of personal tenacity and historical fortuity at the stage of a film's production, at the stage of its 
photography, during editing and postproduction, and at the final stage of its exhibition and consumption... ${ }^{30}$

In the case of Rush to Judgment, the two filmmakers disagreed about how far to extend their vision of commitment.

While de Antonio was politically radical, his commitment to the cause did not necessarily extend into the distribution and exhibition of Rush to Judgment. With the completion of postproduction, he considered his work done, and he left the distribution of Rush to Judgment to professional distributors. He envisioned that the film would reach a popular audience in arthouse or specialty cinemas. Gaining recognition for the work and the questions it raises through theatrical engagements and box-office grosses was important to him, personally, because he was an active filmmaker looking ahead to his next projects. De Antonio was counting on this type of success to allow him to continue making work. And, it must be noted, theatrical release and television broadcast mean a committed documentary can reach much larger audiences, and gain wider press coverage, than circulation only within activist communities.

Unlike de Antonio, Lane saw Rush to Judgment as one tool among many for his activism, and self-promotion, along with his writing, and his radio and television appearances. Lane used the film to disseminate his views about the assassination and conspiracy, but he did not concern himself with the fate of the film as a commercial product. Without prior experience in filmmaking or in the specialty film market, it is possible Lane was ignorant of the need to handle the film strategically. These divergent goals had major consequences for the film's commercial fate, compounding the inauspicious theatrical release managed by an inexperienced distributor navigating an uncertain market.

With the publishing of his book Rush to Judgment, Lane became known as a gadfly, making the rounds on television and radio talk shows to promote his book and discuss the conspiracy to kill President Kennedy. As Lane himself writes in his polemical memoir, A Citizen's Dissent: Mark Lane Replies,

The book did well in each city that I visited, and at my request the [book] tour was extended. Before the tour was completed, I had appeared on approximately five hundred radio and television programs or news interviews and the book was in its sixth printing... In some cities the subject was discussed so frequently and so expertly by the various guests and by the hosts that there came a time when little more could be said. ${ }^{31}$

Not only did Lane talk extensively through the finer points of the book and film's argument, he also agreed to allow a syndicated television program to show part of the film, apparently without compensation and without de Antonio's permission. A Re-Examination of the Warren Commission Findings: A Minority Report was produced by New York's WNEW-TV in August 1966 (Figure 3). At that time, Lane signed a release that allowed a twelve-minute excerpt of the film to be shown. Four months later, he and de Antonio would sign the contract for Impact Films to distribute Rush to Judgment. The contract with Impact Films specified that only five minutes of the film could be shown on television for film or book promotional purposes, so Lane's contract for A Minority Report breached the distribution contract (Figure 4).

The program was first broadcast on November 12,1966, on Metromedia television stations in New York, Washington, Kansas City, and Los Angeles and was then sold in syndication to a 


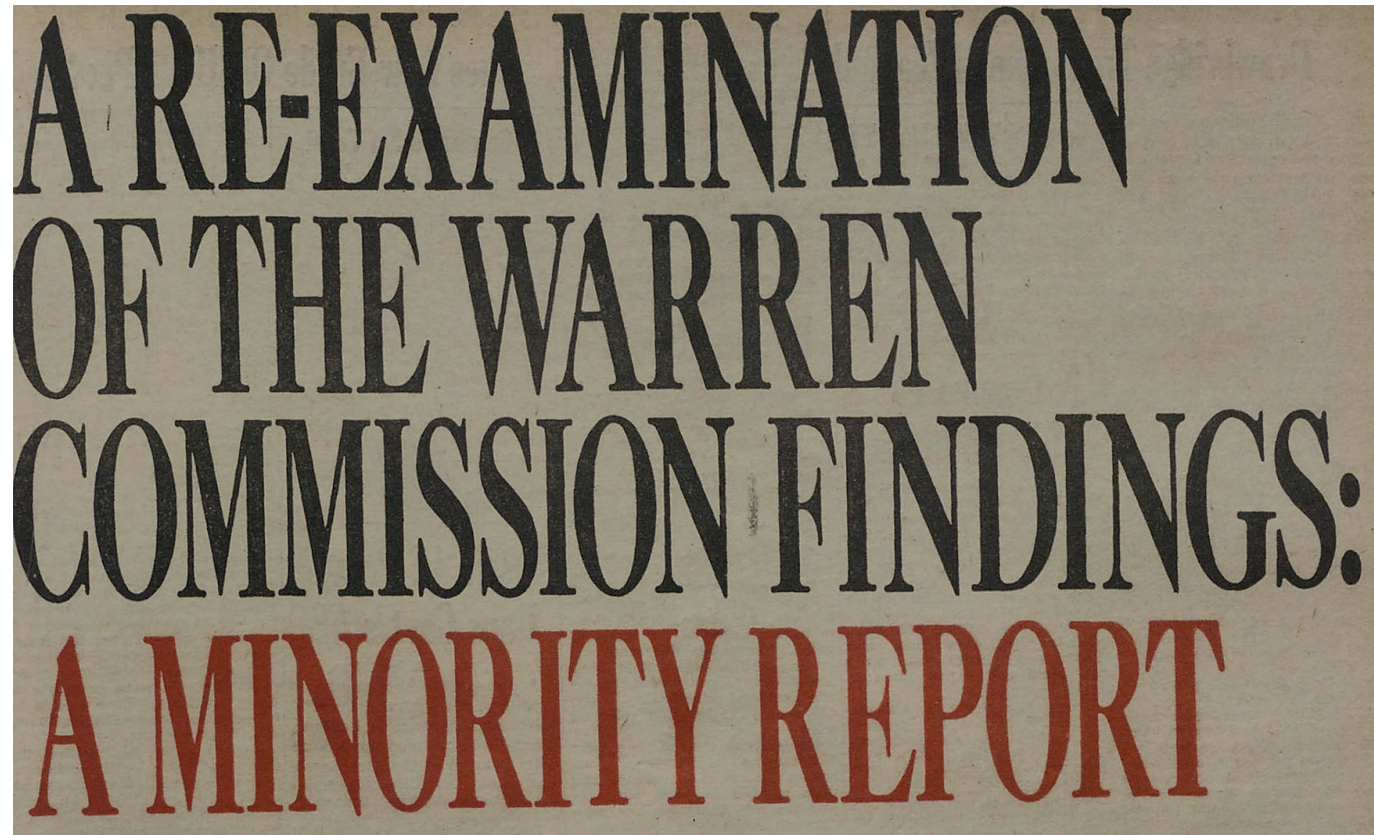

AN IMPORTANT TELEVISION EVENT

According to a recently completed survey of a cross section of the American public, only $32 \%$ feel that the full story of the Kennedy assassination was told in the Warren Commission Report. Two-thirds of all Americans have their doubts. Five doubters each the author of newsmaking books or articles on the controversial subject - confront one another with their challenging, often startling findings in a three-hour taped program now available to stations across the country. Participants are - MARK LANE, attorney and author of "Rush to Judgment" - LEO SAUVAGE, American correspond ent and author of "The Oswald Affair, an Examination of the Contradictions and Omissions of the Warren Report" " HAROLD WEISBERG, author of "Whitewash, The Report on the Warren Report" " PENN JONES, Texas newspaper editor and author of "Forgive My Grief" "JACOB COHEN, author of "The Missing Documents" " JIM BISHOP, author of the forthcoming "The Day Kennedy Was Shot" moderates the program. " DAVID SCHOENBRUN, author and foreign correspondent, hosts.

This important special on a subject making headlines

throughout the world is available immediately!

485 Lexington Ave.

Contact: WOLPER TELEVISION SALES, WC. A METROMEDIA COMPANY
8544 Sunset Blvd. Los Angeles, Calif. 90069 Telephone: OL 2.707

Figure 3. Ad for A Re-Examination of the Warren Commission Findings: A Minority Report, in Variety, November 6, 1966. 
Mark Lane and the other critics of the Warren Commission? The Commission itself? The eminent lawyers who wrote the Warren Report?

Can Louis Nizer, a leading spokesman for the supporters of the Warren Commission findings, accuse these critics of dealing in trivia, minutiae and distortion... of a disservice to the American people? Or are these critics merely guilty of honest, sincere attempts to find the truth?

Only the American public can decide who is irresponsible.

There are two, two-hour debates. The"'Minority Report"with Mark Lane, Leo Sauvage, Harold Weisberg, Penn Jones,Jr., and Jacob Cohen; and the"Majority Rebuttal"'with Louis Nizer, Albert E.Jenner,Jr., Alfredda Scobey and Mark Lane again. They explore the major arguments of both sides.

The "Minority Report"is moderated by Jim Bishop. David Schoenbrun moderates the"Majority Rebuttal,'available in color, and featuring the first face-to-face confrontation between Louis Nizer and Mark Lane. Wolper Television Sales has both of these vital and provocative twohour programs available today.

WOLPER TELEVISION SALES, 485 LEXINGTON AVENUE, NEW YORK, N. Y. 10017 (212) 682-9100 8544 SUNSET BLVD.,HOLLYWOOD, CALIF. 90069 (213) OL 2-7075

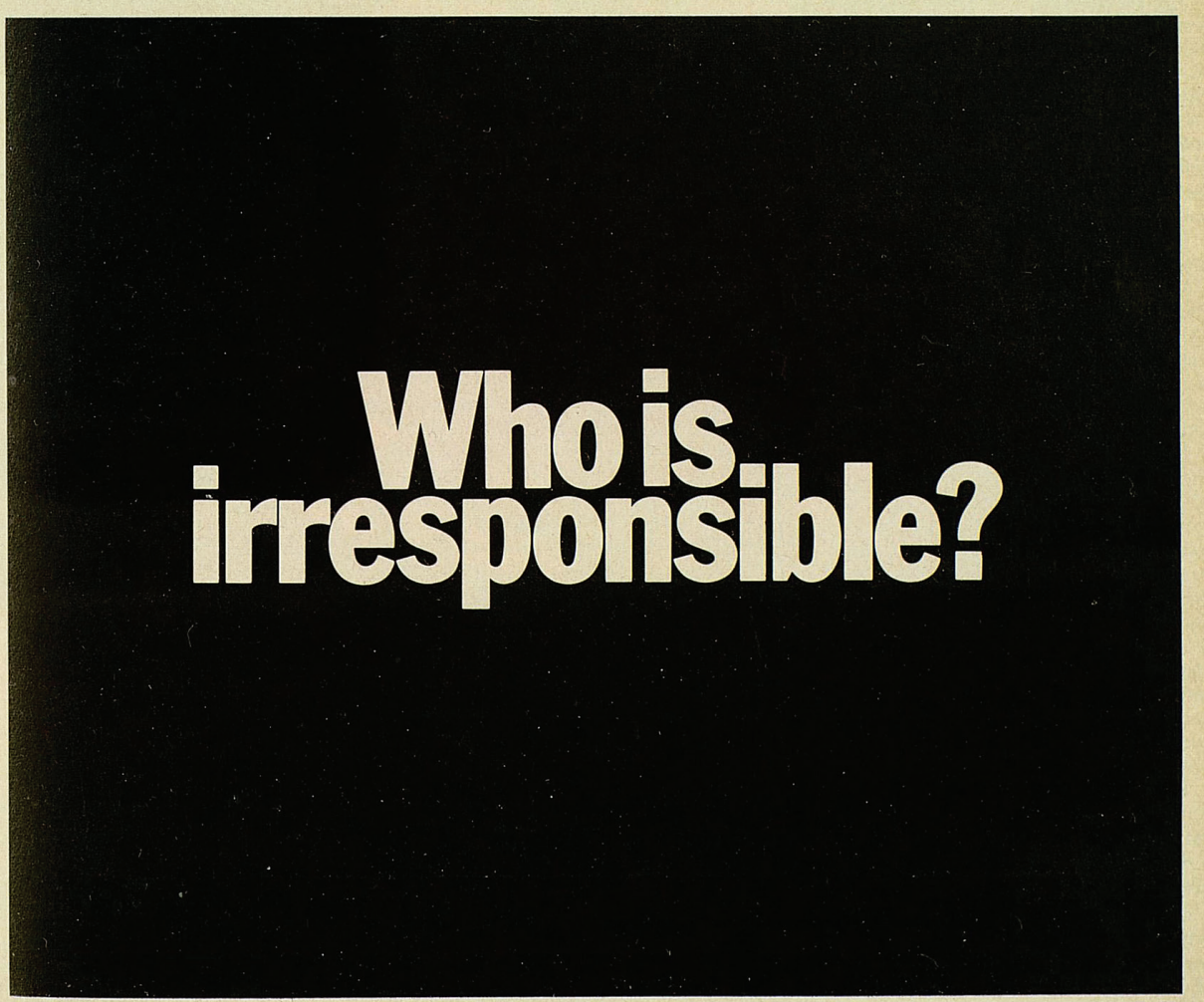

Figure 4. Ad for A Minority Report and A Majority Rebuttal, in Broadcasting, February 13, 1967.

number of other stations. ${ }^{32}$ The program was advertised in Variety and Broadcasting, with a Majority Rebuttal, produced later, advertised as "featuring the first face-to-face confrontation between [leading Warren Commission supporter] Louis Nizer and Mark Lane." ${ }^{33}$ Variety's review of the television program in November 1966 did not mention the film Rush to Judgment by name, only pointing out that "There were numerous slide exhibits (and a couple of filmed 
interviews by Lane of witnesses not called by the Commission)." ${ }^{34}$ Nevertheless, Osen claimed that this program had a direct effect on the market for the film.

Impact tried to prevent further damage from the program in early March 1967. Osen contacted the attorney for Metromedia in an attempt to decrease the amount of Rush to Judgment footage used in A Minority Report. However, Lane countered by arguing that the dissemination of information was more important than protecting the film's interests. He wrote to Rogosin,

It is time we sat back for a moment and thought about the reasons which brought us to this project. We were concerned at the outset, and I hope we still are, with seeing to it that there be a genuine exchange and that the truth be made known. Property rights are at best secondary in this consideration. ${ }^{35}$

Lane did not recognize the potential damage to the film's commercial viability by having such long excerpts of the film broadcast. He even believed that the television program was proof that the film was in position to succeed. He wrote to Osen,

Your job is to show the film in cinemas. Now that the demand in America is so great that television stations are devoting many hours to the discussion, and we have the only film documentary on the subject, it would seem that your job has been rendered quite simple. Why not get to it and stop interfering with agreements that I entered into before I ever met you? ${ }^{36}$

Lane's stance, and subsequent letter to Metromedia's attorney, delayed Impact's ability to change the content of the program, which had already been sold to a number of stations. ${ }^{37}$ In May 1967, de Antonio noticed a symptom of the problem. In a letter to Lane, he wondered about the box office take in New Orleans. "Lionel called this morning to report that distributor's share so far is four thousand dollars for [New Orleans] booking. Since our run was long I can't understand why it is so low." 38 The answer to that question becomes clearer in a letter Osen wrote to Lane, explaining the market situation in New Orleans:

-We lost one drive-in theatre because of the Wolper Sales [Metromedia] syndicated show.

-The entire booking was in jeopardy. The show appeared on major TV station in New Orleans in two parts. I believe the first part of one hour was played on a Tuesday and the second hour on a Thursday, and then, to top it all off, the entire two hour show was repeated on Sunday. The exhibitors took the position that if the public could see it for free, why should they pay $\$ 2.00$ at the box office! After these three telecasts the exhibitors did go through with most of the bookings which had been scheduled.

In addition to the foregoing, there is no dispute whatsoever that the TV sale of the film has been jeopardized or at least reduced materially because of the competition from Wolper Sales. ${ }^{39}$

Osen attributes poor box office to A Minority Report playing on a local station. He also points out that the inclusion of considerable footage from Rush to Judgment in A Minority Report would make selling the broadcast rights much more difficult. While Lane succeeded in drawing attention to the problems with the Warren Report, his endless publicity, often without overtly addressing the film, reduced value of the film to both theater owners and television programmers. 
Although it is little mentioned in the business correspondence between the filmmakers and distributors, Lane's media presence extended into radio, which might have further contributed to market exhaustion. In January 1967, Ted White Productions advertised a radio program called Rush to Judgment in trade journal Broadcasting (Figure 5). "A new radio series based on the nation's \#1 best selling book. Author-attorney Mark Lane discusses the assassination of JFK and the shortcomings of the Warren Report in a 5 minute daily radio series running 39 weeks. ${ }^{40}$ Subsequent issues of Broadcasting recount sales of the series to radio stations around the country. ${ }^{41}$ Lane was also a guest on many talk radio programs, promoting his book and spreading his ideas about the Kennedy assassination. He was so omnipresent that at least one Variety commentator grew weary of him. "[Mort] Sahl has had Mark Lane on frequently, often turned the entire program over to him, and while it's interesting up to a point, that point has long passed." 42 In the absence of show transcripts, it is possible to speculate that Lane promoted the film in these spaces, but the aggregate effect seems to have been further market saturation, which continued to undermine the film's earning potential. ${ }^{43}$

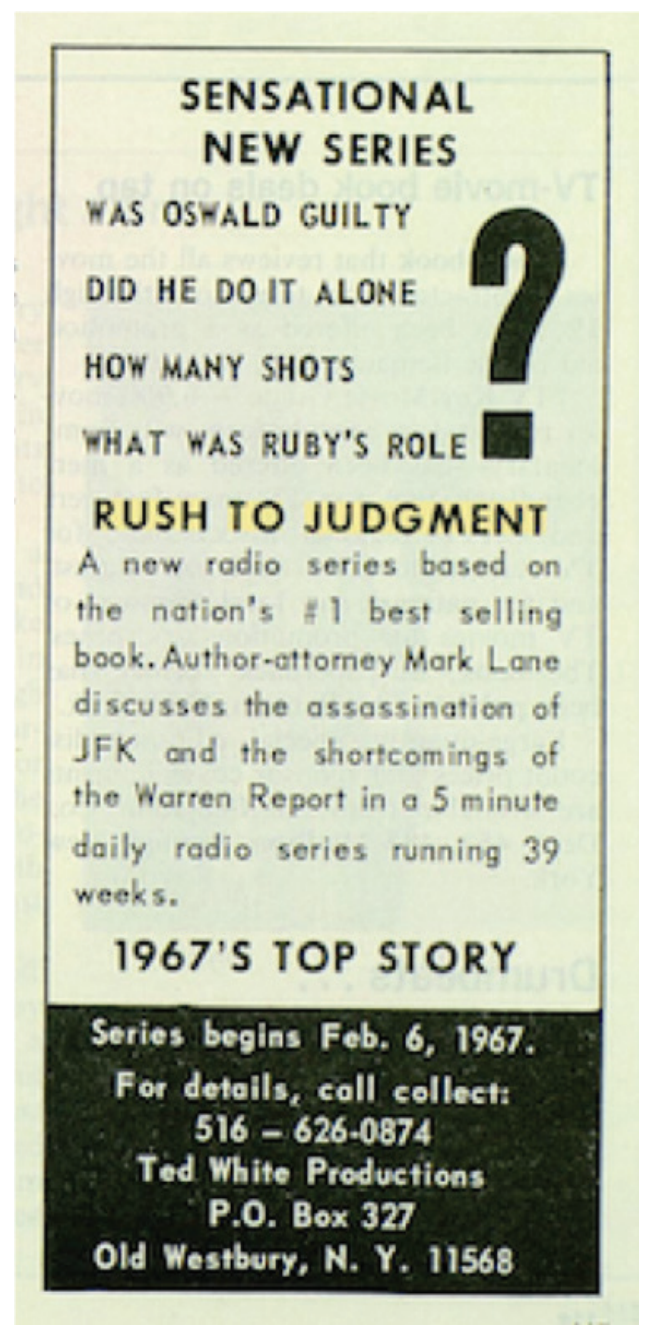

Figure 5. Ad for Rush to Judgment radio series, in Broadcasting, January 2, 1967. 
While Lane and de Antonio shared the same political convictions, their contrary purposes for the film Rush to Judgment came into conflict during the distribution and exhibition of the film. As a filmmaker already developing new projects in the fall of 1966 and spring of 1967, de Antonio depended on Rush to Judgment having a successful theatrical run with healthy box-office returns. However, as a political commentator, author, and professor, Lane was less concerned with the film's theatrical run and more concerned with spreading skepticism of the Warren Report. Combined with his apparent ignorance of the documentary distribution process, Lane signed contracts and made media appearances that proved detrimental to the film's theatrical success. Having a bestselling book of the same name could have attracted exhibitors and audiences to Rush to Judgment. However, because Lane treated the film as just one tool in his arsenal, he compromised Rush to Judgment's commercial prospects.

\section{Across the Pond: Rush to Judgment on BBC Two}

When producing for or licensing their work to television networks, filmmakers often sacrifice editorial control for the large audiences promised by broadcast. There are numerous examples of this conundrum on American television in the 1960s, with documentary films made by former Robert Drew Associates. For example, in 1963, Ricky Leacock and Joyce Chopra made Happy Mother's Day for ABC. The Direct Cinema film shows the dizzying media circus that followed the birth of quintuplets to a family in small-town South Dakota. The film implicitly critiques all those that would exploit this event, including the media. Sponsors had expected a lighter, more celebratory take on the birth, and they rejected the film. ABC reedited the film before air, calling its version Quint City. Granada TV, a British television production company, commissioned David and Albert Maysles to make What's Happening! The Beatles in the USA. When Granada licensed it to CBS, the network edited it and added narration by Carol Burnett. Later in the decade, D.A. Pennebaker and Ricky Leacock made Monterey Pop with backing from ABC. However, the network decided not to air Monterey Pop because executives objected to its risque rock 'n' roll performances. As a result, the filmmakers bought the rights from the network and distributed it through their own distribution company, Leacock-Pennebaker.

Rush to Judgment suffered a similar fate with the BBC. Not only did the BBC control the context in which the film was presented, it also made material changes to the film, such as replacing the original helicopter shots of Dealey Plaza with footage of a model built in the studio. These changes undermined the film's argument, costing Rush to Judgment both commercial and political value and frustrating de Antonio and Lane.

The BBC paid a lucrative license fee of US\$30,000 for the film. The BBC's secondary station, BBC Two, broadcast the film on a Sunday night (January 29, 1967) in prime time. The broadcast was a long event, lasting four and a half hours, to allow for breaks for debate. Broadcasting estimated its audience at seven million viewers. According to a BBC spokesman, this was "the most interest of any show ever on BBC-TV 2." Although negatively reviewed in Variety, the program and viewers' response to it were widely covered by British newspapers and magazines. The Times's television critic, R.W. Cooper, assessed it as "brilliant, highly pertinent television ... The room for doubt will certainly have been brought home to British viewers unfamiliar with the voluminous detail of the Warren report." ${ }^{45}$ The broadcast's wide reach 
and favorable reception were some of the few triumphs that Rush to Judgment and its creators would ever achieve.

Despite British acclaim and a large audience, there were negative consequences to licensing Rush to Judgment to the BBC. In selling the film, the filmmakers gave up control over the film's content and its presentation. The BBC called the program The Death of Kennedy, rather than Rush to Judgment. Although their contract forbade editing the film, the BBC nevertheless replaced the film's helicopter shots of Dealey Plaza with shots of a model built in their studio. This was a major content change. Much of the film's argument involves illustrating witnesses' testimony with these overhead views, so swapping them with different images violated the film's artistic integrity and line of reasoning. These changes were revealed only when Lane arrived in London, and he did not prevent the BBC from airing their version of Rush to Judgment.

The BBC also broke Rush to Judgment into pieces, arranging debates between commentators during and following the film. Lane was on hand to reiterate the points made in the film. Others on the panel included Warren Commission lawyers Arlen Specter and David Belin, and experts on law Lord Devlin and Yale professor Alexander Bickel. Journalist Kenneth Harris and television presenter Cliff Michelmore moderated the discussion. And while Devlin and Bickel were willing to admit that the film's new evidence complicated the Warren Report, Lane was alone in actually refuting the Report. Simply by stacking the panel with two Warren Commission lawyers and two law experts, against a single defender of Oswald, the BBC was able to manipulate the film's presentation.

Neither de Antonio nor Lane was pleased with Rush to Judgment's broadcast on BBC Two. Although the film received television exposure in the United Kingdom, it was in an altered form and shown under a different title. Although Lane earned publicity for his cause through the television event, he claimed that the BBC's arrangements made him appear outgunned. The day after the broadcast, Lane told students at a teach-in that the broadcast "was rigged by the $\mathrm{BBC}$ to put the Warren commission report in the best possible light and to protect the two Warren commission lawyers from having to debate with me." ${ }^{46}$ De Antonio was frustrated with the BBC's alteration of the film and Lane's inability to stop it. In addition, he could not find any British theatrical distributor to acquire the film or even another television network to rebroadcast it. As Bob Heller of ATV Network wrote to de Antonio, "So far as we-and probably every other British television organization-are concerned, the film is a has-been.." ${ }^{27}$ While the BBC Two broadcast was an early triumph for Rush to Judgment, the decision to license the film to a television network removed editorial control from the film's creators and rendered it unworthy of a theatrical release in the United Kingdom. Soon after, the film's meager release in US theaters would compound this disappointment.

\section{Conclusion}

The failure of Rush to Judgment to attract theatrical distributors, exhibitors, and audiences did not stop de Antonio from making political documentaries. On the contrary, he followed it up with In the Year of the Pig, his most confrontational and topical film up to that point. 
Completed in 1969 in the thick of both the undeclared war and the growing anti-war movement, it is a collage film that lays bare the political systems and capitalist machine that led to America's involvement in Vietnam. By that time, however, the filmmaker had fewer illusions about the commercial potential of his films. A 1969 Variety article summarized,

De Antonio comments that his films are now made specifically for U.S. colleges and for European TV. American networks are generally too hesitant to handle any really hard opinion material and even if one can find a theatrical distrib, few exhibs are willing to book dispute-stirring product unless commercial payoff seems assured. ${ }^{48}$

While the months and years after Rush to Judgment's release saw continued growth in the quantity of theatrically released documentaries, only those that advertised spectacle or appealed to popular culture earned strong grosses at the box office. Produced independently of Hollywood, distributors at all levels acquired them, from studios (Warner Bros., Woodstock, 1970) to independent arthouse distributors (Cinema V, Endless Summer, 1966), to exploitation film companies (Peppercorn-Wormser, Festival, 1967), to self-distributors (Leacock-Pennebaker, Dont Look Back, 1967).

Apart from those on rock 'n' roll or pop culture, most documentary films were funneled to the nontheatrical market, a lower risk endeavor that could still yield solid rewards from flatfee rentals to campus film societies and community organizations. This was especially true for documentaries on current affairs and social problems. Companies such as Pathé Contemporary and Grove Press distributed a number of politically potent documentaries to the nontheatrical market. At Grove Press, these included The Troublemakers (1966, dirs. Norman Fruchter, Robert Machover), Titicut Follies (1967, dir. FrederickWiseman), Warrendale (1968, dir. Allan King), and The Queen (1968, dir. Frank Simon). ${ }^{49}$ Pathé Contemporary distributed de Antonio's In the Year of the Pig and The Anderson Platoon (1967, dir. Pierre Schoendoerffer). ${ }^{50}$ Not until 1975 did a current affairs documentary succeed in making waves at the mainstream box office: Hearts and Minds (dir. Peter Davis). Produced by BBS Productions, the company behind Easy Rider and The Last Picture Show, the documentary explored the consequences of the Vietnam War on individual Americans. Initially refused distribution by Columbia Pictures, Warner Bros. took on Hearts and Minds, leading to a profitable theatrical run. The film won the Academy Award for Best Documentary Feature.

Most of the other politically oriented documentarians decided to maintain control of their own work by forming their own production and distribution collectives. By retaining the rights to their films, they could control the content and context for their screenings, most of which, due to market forces, were nontheatrical. Two of the longest running radical film organizations are Newsreel and New Day Films, still extant today. Just months after Rush to Judgment was released, Newsreel met for the first time. At first, the production and distribution collective aimed to screen their films in traditional ways. But their experience was similar to de Antonio and Lane's:

For the most part, however, Newsreel found access to the established distribution channel clogged or unsuitable and the occasional theatrical screening (at the Elgin, the New Yorker, the Gate and The Film-Maker's Cinematheque) served more a fund-raising function than an ongoing, preferred form of release. ${ }^{51}$ 
Rather than concentrate their efforts on the risky, crowded arena of commercial theatrical distribution, Newsreel pivoted to make their films an aggressive, confrontational organizing tool for political leaders. They also distributed other filmmakers' political documentaries, such as The Selling of the Pentagon (1971, dir. Peter Davis) and Attica (1974, dir. Cinda Firestone) on a nonexclusive basis. Had Rush to Judgment been produced later, it is possible that Lane would have partnered with a political film collective to distribute the film. A group like Newsreel or New Day Films (founded 1972) would have focused on using the film as a politically didactic tool, rather than taking on the crowded, high-risk theatrical market.

Rush to Judgment was caught between the world of the commercial, theatrical film market and the DIY spirit of as-yet-unformed political film collectives. While de Antonio and others have attributed the film's commercial failure to politically motivated censorship and intimidation, this explanation is incomplete, failing to account for the wider industrial context of the documentary's release. Bringing the history of American independent cinema to bear on this case, one can see more clearly that the weak institutional framework for the release of independent features in the 1960s hurt Rush to Judgment's chances of success. De Antonio and Lane's different visions of success also handicapped the film: For the former, success meant strong box-office returns and national television broadcast; for the latter, success meant widespread suspicion and rejection of the Warren Report, and a reopening of the investigation into President Kennedy's assassination. Coupled with an inexperienced distributor, these divergent goals led to misunderstandings and mistakes in the theatrical release of Rush to Judgment.

The question of how to circulate a committed documentary remains pertinent to this day: Filmmakers must decide how best to spread their message, which audiences they most want to reach, and whether or not that distribution route will sustain a filmmaking career. While digital technology has made the tools of film production increasingly accessible and internet streaming has swollen the channels on which viewers can access film, documentarians and activists still struggle to design distribution strategies for maximum impact and maximum returns.

${ }^{1}$ Nora Stone teaches film production at the University of Arkansas at Little Rock. Her dissertation (University of Wisconsin-Madison) is an institutional history of the documentary film market. Her work has been published in The Historical Journal of Film, Radio and Television, Los Angeles Review of Books, and Feminist Collections. Her short film Mommy Moments was screened at the Virginia Film Festival in 2017. She produced and art-directed the independent feature film A Dim Valley (in postproduction).

2 Bill Nichols, Representing Reality: Issues and Concepts in Documentary (Bloomington: Indiana University Press, 1991), 48.

${ }^{3}$ Douglas Kellner and Dan Streible, "Introduction," in Emile de Antonio: A Reader, ed. Douglas Kellner (Minneapolis: University of Minnesota Press, 2000), 2.

${ }^{4}$ Vance Kepley Jr., "The Origins of NBC's Project XX in Compilation Documentaries," Journalism Quarterly 61 (1984): 20-6.

5 "Times has 6 for 1964; Sochin Named VP," Boxoffice, April 20, 1964, p. 12. 
${ }^{6}$ For more on the definition of "independent film" in the 1960s, see Yannis Tzioumakis, American Independent Cinema: An Introduction, 2nd ed. (Edinburgh: Edinburgh University Press, 2017).

${ }^{7}$ Janet Staiger, "Part Five: The Hollywood Mode of Production, 1930-60," in The Classical Hollywood Cinema: Film Style E Mode of Production to 1960, ed. David Bordwell, Janet Staiger, and Kristin Thompson (NY: Columbia University Press, 1985), 332.

${ }^{8}$ For more about commercial independent production during the studio era and into the 1960s, see Matthew Bernstein, Walter Wanger, Hollywood Independent (Minneapolis: University of Minnesota Press, 1994).

${ }^{9}$ Yannis Tzioumakis, American Independent Cinema, 96.

${ }^{10}$ For a thorough history of exploitation film, including the changes in exploitation during the 1960s, see Eric Schaefer, Bold! Daring! Shocking! True! A History of Exploitation Films, 1919-1959 (Durham, NC: Duke University Press, 1999).

${ }^{11}$ For more about foreign films in the United States in the postwar era, including a periodization, see Tino Balio, The Foreign Film Renaissance on American Screens, 1946-1973 (Madison: University of Wisconsin Press, 2010).

12 "Multiplying Documentary Films, and Oscar's Puzzling Provisos, Poses Real Rivalry Come Spring," Variety, November 22, 1967, pp. 4, 15.

13 "Big Rental Films of 1967," Variety, January 3, 1968, p. 25.

14 "Picture Grosses: 'Honey Pot' \$8,000, Frisco; 'Cross' Crisp 22G; 'Dylan' Hep 24G," Variety, May 31, 1967, pp. 9, 10. Rick., "Review: Dont Look Back," Variety, June 14, 1967, p. 7. "Picture Grosses: Post-Holiday Blue Nip B'way; 'Emily' Nice \$28,000, 'Dont Look' Mighty 23G, 'Clyde' Giant 69G, 4th, 'Night' Hot 80G," Variety, September 13, 1967, p. 11.

${ }^{15}$ James Kreul, "New York, New Cinema: The Independent Film Community and the Underground Crossover, 1950-1970" (Doctoral dissertation, University of Wisconsin, 2004), 387-8.

${ }^{16}$ Andrea Comiskey, "The Campus Cinematheque: Film Culture at U.S. Universities, 1960-1975," Post Script-Essays in Film and the Humanities 30 (2, winter-spring 2011): 36-52.

17 "Bomb Scares \& Debates at Side Events; Demand High for 'Titicut' Pic," Variety, October 4, 1967, pp. 15, 18.

${ }^{18}$ Stuart Byron, "Ghetto and Hellhole Films: Grove Aims for Campus \& Buffs," Variety, October 11, 1967, pp. 5, 24. By 1971, Grove ceased to release its films theatrically, sending them straight to the nontheatrical market. "Grove Press Cuts but Not Its Film Sector," Variety, May 26, 1971, p. 4.

${ }^{19}$ Loren G. Buchanan, "Review: Rush to Judgment," Motion Picture Herald, May 10, 1967, p. 683.

${ }^{20}$ Letter from De Antonio to Oscar Lowenstein, January 21, 1967, Box 62, Folder: Rush to Judgment correspondence, 1967-1968. De Antonio papers. De Antonio also told Variety that "some Texas exhibitors assert they've been threatened by certain individuals who claim they will 'break up their theatres' if they show the film. 'French Respond to Kennedy Plot Film Based on Mark Lane Ideas'," Variety, March 15, 1967, p. 7. Thomas Waugh elaborated on this assertion, contending that political actors-either 
federal agents or individuals-prevented Rush to Judgment from being shown more widely. He wrote, "Distribution was also a problem: theater owners were threatened with vandalism ..." Thomas Waugh, "Beyond Verite Emile de Antonio and the New Documentary of the 70s," Jump Cut, 10-11 (1976): 33-9.

${ }^{21}$ According to the government documents de Antonio requested under the Freedom of Information Act, the FBI and CIA took no action during production and distribution of the film.

${ }^{22}$ Letter from de Antonio to Oscar Lewenstein, November 25, 1966, in Box 21, Folder 1. 23 "Dirty Word-'Documentary'," Variety, July 7, 1965, p. 5.

${ }^{24}$ Loan agreement of March 14, 1966 between Lionel Rogosin and Judgment Films. Box 63, Folder: Rush to Judgment legal files, 1966, 1967; 1974; 1980; n.d. De Antonio Papers. Robert Ladendorf, "Resistance to Vision: The Effects of Censorship and Other Restraints on Emile de Antonio's Political Documentaries" (Master's thesis, University of Wisconsin-Madison, 1977), 101-2.

${ }^{25}$ Letter from de Antonio to Max Osen, May 20, 1967, Box 62, Folder: Rush to Judgment correspondence, 1967-1968. De Antonio Papers.

${ }^{26}$ Letter from de Antonio to Lionel Rogosin, October 9, 1967, Box 62, Folder: Rush to Judgment correspondence, 1967-1968. De Antonio Papers.

${ }^{27}$ Justin Wyatt, "Donald Rugoff, Cinema V, and Commercial Strategies of 1960s-1970s Art Cinema," Media Industries Journal 4 (1, 2017), 3.

28 "Rogosin Solos Impact; Osen's ‘Amicable' Exit," Variety, October 18, 1967.

29 Thomas Waugh, "Why Documentary Filmmakers Keep Trying to Change the World, or Why People Changing the World Keep Making Documentaries (1984)," in The Right to Play Oneself: Looking Back on Documentary Film, ed. Thomas Waugh (Minneapolis: University of Minnesota, 2011), 6.

${ }^{30}$ Ibid., 7-8.

${ }^{31}$ Mark Lane, A Citizen's Dissent (NY: Holt, Rinehart, and Winston, 1968), 48.

32 "M'media's 3-Hr. 'Minority Report' on Kennedy Murder a Video Rouser," Variety, November 16, 1966, p. 35. In the week after its initial airing, Metromedia's Wolper Television Sales sold it to KPLR, St. Louis; WTIC, Hartford; WTMJ, Milwaukee; KERO, Bakersfield; KBTV, Denver; WWJ, Denver; KVTV, Salt Lake City; KGNB, Hawaii, and KARK, Little Rock.

${ }^{33}$ Ad, Variety, November 9, 1966, p. 49. Ad, Broadcasting, November 11, 1966, p. 21. Ad, Variety, February 8, 1967, p. 33.

34 "M'media's 3-Hr", p. 35.

${ }^{35}$ Letter from Mark Lane to Lionel Rogosin, March 3, 1967, Box 62, Folder: Rush to Judgment correspondence, 1967-1968. De Antonio Papers.

${ }^{36}$ Letter from Mark Lane to Max Osen, March 13, 1967, Box 62, Folder: Rush to Judgment correspondence, 1967-1968. De Antonio Papers.

${ }^{37}$ Letter from Max Osen to de Antonio, March 24, 1967, Box 62, Folder: Rush to Judgment correspondence, 1967-1968. De Antonio Papers.

${ }^{38}$ Letter from de Antonio to Mark Lane, May 4, 1967, Box 62, Folder: Rush to Judgment correspondence, 1967-1968. De Antonio Papers.

${ }^{39}$ Letter from Max Osen to Mark Lane, May 16, 1967, Box 62, Folder: Rush to Judgment correspondence, 1967-1968. De Antonio Papers. 
${ }^{40}$ Ad, Broadcasting, January 2, 1967, p. 117.

${ }^{41}$ The February 20, 1967 issue of Broadcasting reports that Rush to Judgment had been sold to KEST Boise, Idaho; KRCK Ridgecrest, CA; WGWC Selma, AL; WKRG Mobile, AL; WICY Malone, NY; WRCD Dalton, GA; WVLK Lexington, KY; CKXL Calgary, Alberta. Broadcasting, February 20, 1967, p. 66. The April 3, 1967 issue of Broadcasting reports that Rush to Judgment had been sold to KROD El Paso, TX; WHJC Matewan, KY; KGMB Honolulu; WMEL Pensacola, FL. Broadcasting, April 3, 1967, p. 132.

${ }^{42}$ Dave Kaufman, "Talk and Backtalk-New Way of Life on Local Air: Southern California, Nut-Filled Gab-Bag," Variety, January 4, 1967, p. 82.

${ }^{43}$ In fact, a letter from Ted White to de Antonio details the relationship between the radio program and the film. White agreed that "No more than two (2) minutes of any one witness appearing on the film will be used in the radio series" and "Every program in the radio series making use of a segment of the film Rush to Judgment will include the following credit: 'Today's interview was from the Lane-de Antonio film Rush to Judgment'." How often the interviews were used and the film mentioned is unknown. Letter from Ted White to de Antonio, February 9, 1967, Box 62, Folder: Rush to Judgment correspondence, 1967-1968. De Antonio Papers.

44 "BBC Presents Warren Commission Marathon," Broadcasting, February 6, 1967, p. 74. In contrast, the most-watched television program in the 1960s in the United Kingdom, the 1966 World Cup Final, garnered thirty-two million viewers, according to the British Film Institute's website: http://old.bfi.org.uk/features / mostwatched/1960s.html.

${ }^{45}$ R. W. Cooper, "Pertinent Television Study of Kennedy's Death," The Times (London), January 30, 1967, p. 7.

46 "Kennedy Programme Called 'Rigged': Mr. Lane Attacks BBC," The Times (London), January 31, 1967, p. 10.

${ }^{47}$ Letter from Bob Heller to de Antonio, February 2, 1967, Box 62, Folder: Rush to Judgment correspondence, 1967-1968. De Antonio Papers.

48 "Exhibs Sidestep Disputes: Indie Maker Aim: Colleges, Europe," Variety, November 5, 1969, pp. 3, 26. Cinetrees experimented with a theatrical release of In the Year of the Pig by making specialized, focused publicity efforts in one city, Boston. Once that experiment was over, yielding limited success, nontheatrical distributor McGraw Hill/Pathé Contemporary acquired the rights to the film.

${ }^{49}$ Stuart Byron, "Ghetto and Hellhole Films: Grove Aims for Campus \& Buffs," Variety, October 11, 1967, pp. 5, 24.

50 "Foreign Language Feature Reviews: The Anderson Platoon," Boxoffice, January 8, 1968, p. 10.

${ }^{51}$ Bill Nichols, "Newsreel: Film and Revolution"(Master's thesis, University of California Los Angeles, 1972), p. 56.

\section{Bibliography}

Balio, Tino. The Foreign Film Renaissance on American Screens, 1946-1973. Madison: University of Wisconsin Press, 2010. 
Bernstein, Matthew. Walter Wanger: Hollywood Independent. Minneapolis: University of Minnesota Press, 1994.

Bordwell, David, Janet Staiger, and Kristin Thompson. The Classical Hollywood Cinema: Film Style \& Mode of Production to 1960. New York: Columbia University Press, 1985.

Comiskey, Andrea. "The Campus Cinematheque: Film Culture at U.S. Universities, 1960-1975." Post Script-Essays in Film and the Humanities 30, no. 2 (winter-spring 2011): 36-52.

Kellner, Douglas, and Dan Streible. Emile de Antonio: A Reader. Minneapolis: University of Minnesota Press, 2000.

Kepley, Vance Jr. “The Origins of NBC's Project XX in Compilation Documentaries." Journalism Quarterly 61 (1984): 20-6.

Kreul, James. New York, New Cinema: The Independent Film Community and the Underground Crossover, 1950-1970. Doctoral dissertation, University of Wisconsin-Madison, 2004, 387-8.

Ladendorf, Robert. Resistance to Vision: The Effects of Censorship and Other Restraints on Emile de Antonio's Political Documentaries. Master's thesis, University of WisconsinMadison, Madison, 1977.

Lane, Mark. A Citizen's Dissent. New York: Holt, Rinehart and Winston, 1968.

Nichols, Bill. Newsreel: Film and Revolution. Master's thesis, University of California Los Angeles, Los Angeles, 1972.

Nichols, Bill. Representing Reality: Issues and Concepts in Documentary. Bloomington: Indiana University Press, 1991.

Schaefer, Eric. Bold! Daring! Shocking! True! A History of Exploitation Films, 1919-1959. Durham, NC: Duke University Press, 1999.

Tzioumakis, Yannis. American Independent Cinema: An Introduction, 2nd ed. Edinburgh: Edinburgh University Press, 2017.

Waugh, Thomas. "Why Documentary Filmmakers Keep Trying to Change the World, or Why People Changing the World Keep Making Documentaries (1984)." In The Right to Play Oneself: Looking Back on Documentary Film, edited by Thomas Waugh. Minneapolis: University of Minnesota, 2011, 1-18. 